\title{
METABOLISM OF RHESUS MONKEY SPERMATOZOA
}

\author{
D. D. HOSKINS AND D. L. PATTERSON \\ Department of Biochemistry, Oregon Regional Primate Research Center, Beaverton, \\ Oregon, and Department of Biochemistry, University of Oregon Medical School, Portland, \\ Oregon, U.S.A.
}

(Received 16th Fune 1967)

\begin{abstract}
Summary. Rhesus monkey (Macaca mulatta) spermatozoa were found to have a high but variable rate of aerobic fructolysis. Efforts to correlate the rate of aerobic fructolysis with spermatozoal motility led to the development of a radiochemical method for determination of lactate. Rates of aerobic fructolysis, regulated by titration with fluoride and iodoacetate, have been shown to be positively correlated with motility ratings. Spermatozoal motility was depressed but not abolished by titration with antimycin $\mathrm{A}$, amytal, cyanide, and 2- $\mathcal{N}$-heptyl-4-hydroxyquinoline $\mathcal{N}$-oxide in the presence of fructose. Titration of washed spermatozoa with quinoline $\mathcal{N}$-oxide in the absence of fructose showed respiratory rates to be positively correlated with motility. Incubation of washed spermatozoa under anaerobic conditions in the presence of fructose caused a slight but perceptible loss in motility. Motility was completely abolished by incubation of washed spermatozoa in the absence of fructose but was restored by aeration.
\end{abstract}

Monkey spermatozoa were further shown to be characterized by a rate of endogenous respiration comparable to that reported for the spermatozoa of many domestic animals, including the ram and bull. Substrates which significantly stimulated respiration were pyruvate, succinate, a-ketoglutarate and malate. A mechanism for the decarboxylation of pyruvate independent of respiration (pyruvate dismutation) was indicated by the fact that more than twice as much radio-activity was found in evolved ${ }^{14} \mathrm{CO}_{2}$ when $\left[1-{ }^{14} \mathrm{C}\right]$ pyruvate was used as substrate than was found when an equal amount of $\left[3-{ }^{14} \mathrm{C}\right]$ pyruvate was used. ${ }^{14} \mathrm{CO}_{2}$ formation from the latter compound was almost completely inhibited by $2 \cdot 1 \mu \mathrm{M}$ antimycin $\mathrm{A} ;{ }^{14} \mathrm{CO}_{2}$ evolution from the former was inhibited less than $30 \% \cdot\left[5,6-{ }^{14} \mathrm{C}\right]$ Isocitrate and $\left[{ }^{14} \mathrm{CH}_{3}\right]$ choline were oxidized, as measured by ${ }^{14} \mathrm{CO}_{2}$ evolution, at rates approximately $1 / 10$ and $1 / 50$, respectively, that of pyruvate. The rate of oxidation of each compound was diminished by electron transport chain inhibitors.

\section{INTRODUCTION}

Biochemical studies on the metabolism of human spermatozoa are hindered by the existence of uncontrollable variables such as frequency of collection, age of samples, and procurement of multiple samples from a single subject over a 
protracted period of time. Approaches to basic problems of human spermatozoal physiology should be facilitated by preliminary study of the spermatozoa of closely related species of subhuman primates. Such studies appear to be warranted in view of the considerable inter-species variation in the metabolism of spermatozoa of various domestic animals (Mann, 1964). The development by Mastroianni \& Manson (1963) of a reliable electro-ejaculation technique for collection of monkey semen has given impetus to the studies described here. In the present paper, we wish to report on the fructolytic and respiratory capacities of the spermatozoa of the rhesus monkey (Macaca mulatta); to relate these capacities to the maintenance of spermatozoal motility; and to document the existence and properties of specific enzymic reactions of both the fructolytic and respiratory metabolic pathways.

\section{Spermatozoa}

\section{MATERIALS AND METHODS}

Semen was collected by the electro-ejaculation method of Mastroianni \& Manson (1963) from seven animals ranging in weight from 7 to $10 \mathrm{~kg}$. Spermatozoa were washed and suspended in Norman-Johnson's solution (Norman, Goldberg, Porterfield \& Johnson, 1960) containing fructose at a level of $2 \mathrm{mg} / \mathrm{ml}$ as previously described (Hoskins \& Patterson, 1967; abbreviated herein $\mathrm{N}-\mathrm{J}-\mathrm{F}$ ) unless otherwise indicated. Spermatozoal motility was rated according to the method of Aalbers, Mann \& Polge (1961).

\section{Assays}

Lactic acid, when measured enzymatically, was determined according to Friedland \& Dietrich (1961) employing a zinc lactate standard. Fructose determination was based on the procedures of Roe (1934) and Mann (1948) as described by Rothschild (1962). Measurement of ${ }^{14} \mathrm{CO}_{2}$ evolution in Warburg vessels was based on trapping the gas in Hyamine 10X hydroxide (Passman, Radin \& Cooper, 1956). Filter papers were transferred to vials containing $15 \mathrm{ml}$ of counting solution. The centre wells of the vessels were washed twice with $100 \mu \mathrm{l}$ portions of base and the combined washings added to counting vials. Samples were counted in a Packard Tri-Garb liquid scintillation apparatus with maximum counting efficiency being obtained after $10 \mathrm{hr}$. Counting solution was composed of redistilled toluene containing $5 \mathrm{~g}$ of $2^{\prime}, 5^{\prime}$-diphenyloxazole and $0.3 \mathrm{~g}$ of $p$-bis- $2^{\prime}\left(5^{\prime}\right.$-phenyloxazolyl)-benzene $/ 1$. $\left[{ }^{14} \mathrm{C}\right]$ Lactate on paper was counted after $24 \mathrm{hr}$ in the scintillation apparatus under identical conditions. Acetokinase was purified from Escherichia coli (strain W, ATCG 9637) by the method of Rose (1955) and used to determine acetate according to the method described by this author. Pyruvate was assayed as described by Peterson, Beatty \& Bocek (1963). Oxygen consumption was measured at $37^{\circ} \mathrm{C}$ using either a Gilson Medical Electronics Model K Oxygraph or a conventional Warburg apparatus. Manometric measurements were carried out in air at a shaking rate of 70 to 80 oscillations/min.

\section{$\left[{ }^{14} \mathrm{C}\right]$ Pyruvate chromatography}

Purity of the sodium salts of $\left[1-{ }^{14} \mathrm{C}\right]$ and $\left[3-{ }^{14} \mathrm{C}\right]$ pyruvate obtained commercially was checked by chromatography on Dowex 1-x2 $\left(\mathrm{Cl}^{-}\right), 200$ to 400 
mesh (Von Korff, 1964). The carboxyl and methyl labelled compounds were found to be 88 and $91 \%$ pure, respectively. Small amounts of both slower and faster eluting labelled components were observed as contaminants. Labelled pyruvate solutions were stored frozen in $1 \mathrm{~N}-\mathrm{HCl}$.

\section{Reagents}

$\left[1-{ }^{14} \mathrm{C}\right]$ Pyruvate, $\left[3-{ }^{14} \mathrm{C}\right]$ pyruvate, $\left[\mathrm{U}^{1{ }^{14}} \mathrm{C}\right]$ fructose, $\left[5,6-{ }^{14} \mathrm{C}\right]$ isocitrate and $\left[{ }^{14} \mathrm{CH}_{3}\right]$ choline chloride were obtained from the New England Nuclear Corp. Antimycin A and 2- $\mathcal{N}$-heptyl-4-hydroxyquinoline $\mathcal{N}$-oxide were products of the Sigma Chemical Co. Amytal was purchased from Eli Lilly \& Co.

\section{RESULTS}

\section{Aerobic fructolysis as assessed by the rate of fructose utilization}

The semen of the rhesus monkey is characterized by a solidification process occurring almost immediately after ejaculation, with resultant formation of a coagulum reminiscent of the so-called copulatory plug. Solidification is followed, at least in vitro, by gradual release over a several-hour period of a sperm-rich fluid 'exudate' containing, in addition, high concentrations of fructose; determination of fructose in such exudates of six animals gave a mean value of $12.6 \pm$ $0.4 \mathrm{mg} / \mathrm{ml}$. As a rule, the exudates were separated from the plug following incubation at $37^{\circ} \mathrm{G}$ for $45 \mathrm{~min}$. However, for measurements of the rate of fructose utilization, sufficient exudate was available already after $10 \mathrm{~min}$ incubation. This was then diluted with an equal volume of Ca-free Ringerphosphate solution, $\mathrm{pH} \mathrm{7.4} \mathrm{(Mann,} \mathrm{1946).} \mathrm{Determination} \mathrm{of} \mathrm{the} \mathrm{'fructolysis}$ index' ( $\mathrm{mg}$ fructose utilized by $10^{9}$ spermatozoa in $1 \mathrm{hr}$ at $37^{\circ} \mathrm{C}$, Mann, 1948) in the exuded seminal fluids of four animals showed the index to be high, but variable, with mean values of $4 \cdot 0 \pm 2 \cdot 2,2 \cdot 8 \pm 1 \cdot 0$ and $1.9 \pm 0.4$ being obtained for the first, second and third 1-hr intervals after ejaculation. In the four samples studied, initial fructose concentrations were $12.5 \pm 1.3 \mathrm{mg} / \mathrm{ml}$. Although the magnitudes of the indices were positively correlated with the initial fructose levels (Freund, Mixner \& Mather, 1957, 1959; Mann, 1964), it is doubtful that the variability in rates can be ascribed solely to an effect of substrate concentration. Such an effect would necessitate postulation of a $K_{\mathrm{m}}$ for monkey sperm hexokinase (generally considered to be the rate-limiting step in glycolysis) considerably greater than that recently reported by Rikmenspoel \& Caputo (1966) for bull sperm hexokinase.

\section{Radiochemical estimation of lactate}

The small volume of seminal fluid exuded from a single solidified ejaculate, which, with some animals, did not exceed 200 to $300 \mu$ l, indicated that a more sensitive method than one based on fructose disappearance would be desirable for studies on the relation between the rate of aerobic fructolysis and sperm motility. It was decided, therefore, to measure the formation of lactic acid, a compound easily determined in microgram quantities. Unfortunately, the sensitive colorimetric lactate method of Barker \& Summerson (1941) was found to be unsatisfactory due to interference from a spurious green colour on addition of the $p$-hydroxyphenyl reagent. Therefore, a radiochemical method for 
determination of lactate was subsequently developed. Basically, it depends upon measuring the formation of $\left[{ }^{14} \mathrm{C}\right]$ lactate from a known amount of uniformly labelled fructose ([U- $\left.{ }^{14} \mathrm{C}\right]$ fructose). It is applicable only to washed spermatozoa. The detailed procedure is as follows: exuded spermatozoa are washed with pre-warmed $\left(37^{\circ} \mathrm{C}\right) \mathrm{N}-\mathrm{J}$-F solution and suspended in fresh N-J-F solution to give sperm concentrations in the range of 1 to $4 \times 10^{8} / \mathrm{ml}$. Into one side-arm of a micro-Warburg vessel are placed $200 \mu \mathrm{l}$ of sperm suspension, $50 \mu \mathrm{l}$ of $\left[\mathrm{U}_{-}{ }^{14} \mathrm{C}\right]-$ fructose solution (approximately $0.7 \mu \mathrm{c}$ ), and $25 \mu \mathrm{l}$ of $0.16 \mathrm{M}$-sodium phosphate buffer, $\mathrm{pH} 7 \cdot 2$. The second side-arm contains $200 \mu \mathrm{l}$ of $25 \%$ trichloroacetic acid, and the centre well $100 \mu \mathrm{l}$ of Hyamine 10X hydroxide adsorbed on a piece of fluted Whatman No. 30 paper measuring $1.5 \times 2.5 \mathrm{~cm}$. Assays are made in duplicate or triplicate. Control flasks contain all components except spermatozoa. After $1 \mathrm{hr}$ incubation at $37^{\circ} \mathrm{C}$ in a conventional Warburg apparatus, at a shaking rate of 70 to 80 oscillations/min, the contents of both side-arms are tipped into the main compartment and shaking is continued for $1 \mathrm{hr}$ to insure complete liberation of ${ }^{14} \mathrm{CO}_{2}$. The protein-free supernatant solution obtained after centrifugation at $25,000 \mathrm{~g}$ for $30 \mathrm{~min}$ is used for lactate analysis. To $0.2 \mathrm{ml}$ of the deproteinized solution in a tube capable of withstanding considerable centrifugal force, are added $1.3 \mathrm{ml}$ of water, $0.5 \mathrm{ml}$ of saturated $\mathrm{CuSO}_{4}$ (approximately $40 \%$ ), and $1.0 \mathrm{~g}$ of $\mathrm{Ca}(\mathrm{OH})_{2}$ and the mixture is dispersed by vigorous shaking. The precipitate is redispersed several times during a 30-min period and the mixture subsequently centrifuged at $28,000 \mathrm{~g}$ for $15 \mathrm{~min}$. A $200-\mu \mathrm{l}$ portion of the resultant supernate is applied to a $2 \times 6 \mathrm{~cm}$ strip of Whatman No. 30 paper, the paper dried under a stream of warm air and added to $15.0 \mathrm{ml}$ of scintillation counting fluid and $0.3 \mathrm{ml}$ Hyamine $10 \mathrm{X}$ hydroxide. Under these conditions labelled lactate is counted with an efficiency of approximately $65 \%$. For some unknown reason, efficiency increases gradually with time to a maximum at $24 \mathrm{hr}$, the total counts after this interval being some $20 \%$ greater than those initially recorded. The radio-activity of $\left[{ }^{14} \mathrm{C}\right]$ lactate samples reported in this paper are those obtained 18 to $24 \mathrm{hr}$ after immersion of the $\left[{ }^{14} \mathrm{C}\right]$ lactate impregnated papers in counting solution.

The usefulness of the method described for routine lactate formation measurements depends on fulfilment of a number of obvious conditions, namely, that $\left[{ }^{14} \mathrm{C}\right]$ lactate is all that is being counted, that proportionality is obtained between sperm concentration and lactate formation, and that the procedure may be replicated. Development of the procedure was aided by the observation (C. H. Beatty, personal communication) that precipitation of $\left[{ }^{14} \mathrm{C}\right]$ glucose from solutions containing $\left[{ }^{14} \mathrm{C}\right]$ lactate is facilitated by the use of saturated $\mathrm{CuSO}_{4}$ solutions in the Cu-lime precipitation step of the Barker \& Summerson (1941) colorimetric method. The use of high levels of $\mathrm{CuSO}_{4}$ has similarly permitted an essentially complete separation of $\left[{ }^{14} \mathrm{C}\right]$ fructose from $\left[{ }^{14} \mathrm{C}\right]$ lactate. Experiments with known levels of labelled compounds have shown the former to be almost completely removed while the latter is completely recovered. Chromatography on paper of a desalted sample of a $\mathrm{Cu}$-lime supernatant solution obtained following a typical incubation and deproteinization procedure, revealed the presence of a single compound identifiable as $\left[{ }^{14} \mathrm{C}\right]$ lactate (Table 1). The supernantant, which contained no detectable $\left[{ }^{14} \mathrm{C}\right]$ fructose, was 
desalted by chromatography on a Sephadex G-10 column before chromatography on paper. All of the isotope applied to the column was recovered in a single peak. Eluates were concentrated by lyophilization.

\section{TABLE 1}

PAPER GHROMATOGRAPHIC IDENTIFIGATION OF LAGTATE AS THE SOLE LABELLED COMPONENT OF DESALTED COPPER-LIME SUPERNATANT SOLUTION

\begin{tabular}{l|c|c|c}
\hline \multicolumn{1}{c|}{ Solvent system* } & \multicolumn{3}{|c}{$R_{F}$} \\
\cline { 2 - 4 } & {$\left[{ }^{14} C\right]$ Fructose } & {$\left[{ }^{14}\right.$ C $]$ Lactate } & Unknown \\
\hline $\begin{array}{l}\text { n-Butanol-formic acid-water } \\
\text { (4:1:5, organic phase) }\end{array}$ & 0.69 & 0.79 & 0.78 \\
$\begin{array}{l}\text { Water-saturated phenol } \\
\text { (formic acid atmosphere) }\end{array}$ & 0.08 & 0.77 & 0.78 \\
\hline
\end{tabular}

* Ascending technique, Whatman No. 1 paper. Development time, $8 \mathrm{hr}$.

Validity of the method was substantiated by demonstration of the equivalence of the amount of lactate formed from fructose as measured either radiochemically by the procedure described above or as measured enzymatically (Friedland \& Dietrich, 1961). In the experiment shown in Table 2, fructolysis

TABLE 2

COMPARISON OF RADIOCHEMICAL AND ENZYMATIC METHODS FOR DETERMINATION OF LACTATE

\begin{tabular}{c|c|c|c}
\hline \multirow{2}{*}{$\begin{array}{c}\text { Flask } \\
\text { no. }\end{array}$} & $\begin{array}{c}\text { Fructolysis interrupted } \\
\text { with: }\end{array}$ & \multicolumn{2}{|c}{ Lactate formed $(\mu \mathrm{g})$} \\
\hline 1 & $\begin{array}{c}\text { Ice-water } \\
2\end{array}$ & $\begin{array}{c}\text { Ice-water } \\
\text { Acid }\end{array}$ & $177 \cdot 0 \pm 2 \cdot 7$ \\
3 & $158 \cdot 0 \pm 2 \cdot 4$ & $190 \cdot 4$ \\
\hline
\end{tabular}

Sperm concentration: $9.5 \times 10 / 7$ flask.

was interrupted by immersion of flasks in an ice bath (to avoid interference by acid with the enzymatic assay) and the amount of radiolactate formed was measured by both methods. For purposes of comparison, the amount of radiolactate formed under conditions in which the reaction is stopped with acid (the standard procedure) is also shown. Calculation of the amount of radiolactate formed from radiofructose is determined by use of the equation:

Total lactate formed/flask $(\mu \mathrm{g})$

$$
=\frac{(\text { counts } / \mathrm{min} / 0 \cdot 2 \mathrm{ml} \mathrm{Cu} \text {-lime supernate })(23 \cdot 8)}{\left.\left[\mathrm{U}_{-}{ }^{14} \mathrm{C}\right] \text { fructose specific activity (counts } / \mathrm{min} / \mu \mathrm{g}\right)},
$$

where the number 23.8 represented a dilution factor based on the use of $200 \mu$ l of acid-denatured supernatant solution for Cu-lime precipitation (total solution, $475 \mu \mathrm{l}$ ) and on the application of $200 \mu \mathrm{l}$ of $\mathrm{Cu}$-lime supernatant solution to 
filter paper strips for counting. At the conclusion of the experiment, the specific activity of $\left[\mathrm{U}-{ }^{14} \mathrm{C}\right]$ fructose was determined in the contents of control flasks.

Proportionality between sperm concentration and $\left[{ }^{14} \mathrm{C}\right]$ lactate formation (100 $\mu$ l portions of Cu-lime supernate) is shown in Text-fig. 1. Deviation from

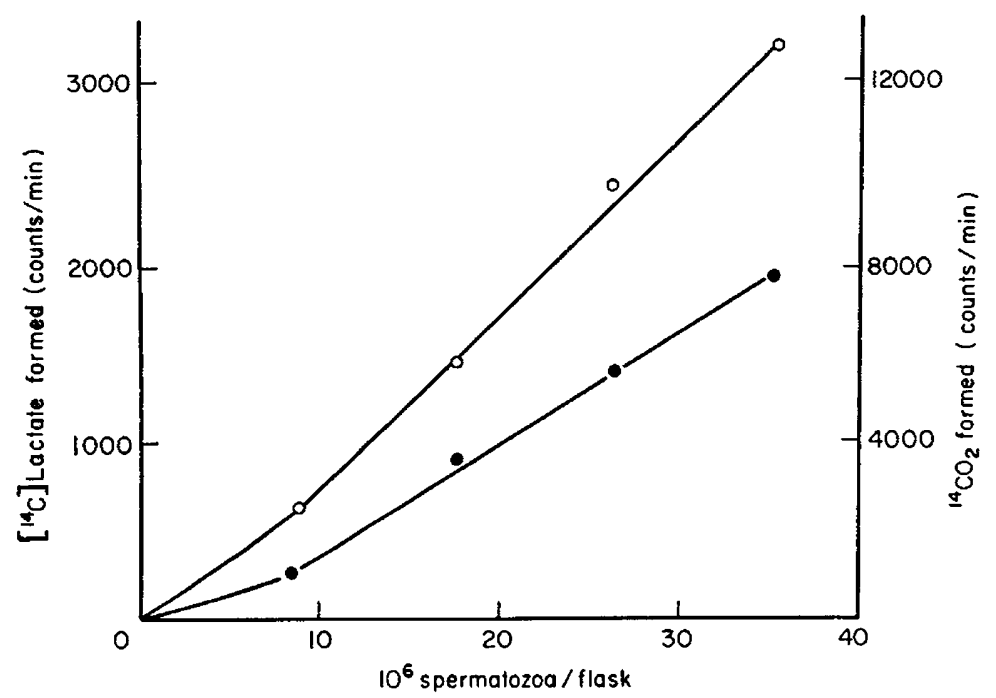

TeXT-FIG. 1. $\left[{ }^{14} \mathrm{C}\right]$ Lactate $(0)$ and ${ }^{14} \mathrm{CO}_{2}(0)$ formed from the aerobic oxidation of $\left[\mathrm{U} .{ }^{14} \mathrm{C}\right]$ fructose as a function of sperm concentration. Sperm concentration range: 0.85 to $3.5 \times 10^{7}$ spermatozoa/flask. The activities shown for ${ }^{14} \mathrm{CO}_{2}$ evolution and $\left[{ }^{14} \mathrm{C}\right]$ lactate formation, up to approximately 13,000 and 3000 counts/min, respectively, are the measured activities obtained directly from the scintillation apparatus. The ${ }^{14} \mathrm{CO}_{2}$ activities account for all the gas evolved in each flask; total $\left[{ }^{14} \mathrm{C}\right]$ lactate activity in each flask may be obtained by multiplying by the dilution factor 23.8 as defined in the text.

linearity is observed at sperm concentrations of $2 \times 10^{6} / \mathrm{ml}$ or less, due, presumably, to dilution effects. The ease with which the measurement of lactate formation is replicated is shown by the data in Table 3. It appears that the radiochemical method described above is a valid and sensitive procedure for estimation of lactate formation from fructose by washed monkey spermatozoa.

TABLE 3

\begin{tabular}{|c|c|c|c|}
\hline System & $\begin{array}{l}\text { Total }{ }^{14} \mathrm{CO}_{2} \text { formation } \\
\left(\text { counts } / \text { min } \times 10^{-4}\right)\end{array}$ & $\begin{array}{c}\text { Total }\left[{ }^{14} \mathrm{C}\right] \text { lactate } \\
\text { formation } \\
\left(\text { counts/min } \times 10^{-4}\right)\end{array}$ & $\begin{array}{l}\text { Ratio: } \\
\text { counts/min lactate/ } \\
\text { counts/min } \mathrm{CO}_{2}\end{array}$ \\
\hline $\begin{array}{l}\text { Non-enzymic } \\
\text { Complete } \\
\text { Complete } \\
\text { Complete }\end{array}$ & $\begin{array}{l}0.04 \pm 0.00 \\
2.58 \pm 0.02 \\
2 \cdot 73 \pm 0.02 \\
2 \cdot 74 \pm 0.02\end{array}$ & $\begin{array}{r}1.58 \pm 0.01 \\
18 \cdot 17 \pm 0.04 \\
19.23 \pm 0.04 \\
18.54 \pm 0.04\end{array}$ & $\begin{array}{l}7 \cdot 04 \\
7 \cdot 04 \\
6 \cdot 77\end{array}$ \\
\hline
\end{tabular}

Effect of metabolic inhibitors on $\left[{ }^{14} \mathrm{C}\right]$ lactate formation, ${ }^{14} \mathrm{CO}_{2}$ evolution, and sperm motility

Attempts were subsequently made to correlate rates of aerobic fructolysis and respiration, regulated by titration with metabolic inhibitors, with the 
motility ratings of washed spermatozoa. Aerobic fructolysis and respiration were measured by determining the amount of $\left[{ }^{14} \mathrm{C}\right]$ lactate and ${ }^{14} \mathrm{CO}_{2}$, respectively, formed from $\left[\mathrm{U}_{-}{ }^{14} \mathrm{C}\right]$ fructose. The effects of varying concentrations of fluoride (fructolysis, enolase), amytal (respiration, NADH dehydrogenase), and antimycin $\mathrm{A}$ (respiration, cyt.b) on sperm motility, aerobic fructolysis, and respiration are shown in Table 4. Spermatozoa used in Exp. 1 were washed with

TABLE 4

EFFECT OF METABOLIC INHIBITORS ON [ $\left.{ }^{14} \mathrm{C}\right]$ LACTATE FORMATION, ${ }^{14} \mathrm{CO}_{2}$ EVOLUTION AND SPERM MOTILITY

\begin{tabular}{|c|c|c|c|c|}
\hline \multirow{2}{*}{$\begin{array}{l}\text { Exp. } \\
\text { no. }\end{array}$} & \multirow[t]{2}{*}{ Inhibitor } & \multicolumn{2}{|c|}{$\begin{array}{l}\text { Radiochemical products } \\
\left(\text { counts/min/flask } \times 10^{-3}\right)\end{array}$} & \multirow{2}{*}{$\begin{array}{c}\text { Motility rating } \\
\text { (after } 1 \mathrm{hr} \\
\text { incubation) }\end{array}$} \\
\hline & & $\mathrm{CO}_{2}$ & Lactate & \\
\hline 1 & $\begin{array}{l}\text { None } \\
9 \cdot 10 \mu \mathrm{M}-\mathrm{NaF} \\
0.91 \mathrm{~mm}-\mathrm{NaF} \\
9.10 \mathrm{~mm}-\mathrm{NaF}\end{array}$ & $\begin{array}{l}3 \cdot 3+0.06 \\
2 \cdot 83+0.05 \\
2 \cdot 76 \pm 0.05 \\
1.52 \pm 0.04\end{array}$ & $\begin{array}{r}35.78 \pm 0.92 \\
48.35 \pm 1 \cdot 12 \\
37.96 \pm 0.95 \\
8.46 \pm 0.48\end{array}$ & $\begin{array}{l}4 / 2 \\
3 / 1 \\
1 / 0 \\
0 / 0\end{array}$ \\
\hline 2 & $\begin{array}{l}\text { None } \\
0.42 \mathrm{~mm} \text {-amytal } \\
0.84 \mathrm{~mm} \text {-amytal } \\
1.68 \mathrm{~mm} \text {-amytal }\end{array}$ & $\begin{array}{l}5.4 \pm 0.07 \\
4.42 \pm 0.07 \\
2.85 \pm 0.05 \\
1.46 \pm 0.04\end{array}$ & $\begin{array}{l}53.8 \pm 0.5 \\
63.3 \pm 0.5 \\
67.9 \pm 0.5 \\
67.9 \pm 0.5\end{array}$ & $\begin{array}{l}6 / 3 \\
6 / 2 \\
6 / 2 \\
6 / 0\end{array}$ \\
\hline 3 & $\begin{array}{l}\text { None } \\
0 \cdot 07 \mu \mathrm{M} \text {-antimycin A } \\
0 \cdot 72 \mu \mathrm{M} \text {-antimycin A } \\
72 \cdot 0 \mu \mathrm{M} \text {-antimycin A }\end{array}$ & $\begin{array}{l}8.99 \pm 0.09 \\
1.51 \pm 0.04 \\
1.56 \pm 0.04 \\
0.86 \pm 0.03\end{array}$ & $\begin{array}{l}74 \cdot 4 \pm 1.3 \\
70 \cdot 7 \pm 1 \cdot 3 \\
68 \cdot 8 \pm 1 \cdot 3 \\
72.5 \pm 1 \cdot 3\end{array}$ & $\begin{array}{l}8 / 4 \\
7 / 2 \\
7 / 1 \\
7 / 1\end{array}$ \\
\hline
\end{tabular}

$\mathrm{Ca}^{++}$-free Ringer solution to prevent precipitation of $\mathrm{CaF}_{2}$. Sperm concentrations were $1 \cdot 6,1 \cdot 1$ and $1 \cdot 1 \times 10^{8} / \mathrm{ml}$ in Exps. 1,2 and 3, respectively. Inhibitors and spermatozoa were incubated for $5 \mathrm{~min}$ at $37^{\circ} \mathrm{C}$ before addition of $0.5 \mu \mathrm{c}$ $\left[\mathrm{U}-{ }^{14} \mathrm{C}\right]$ fructose. A positive correlation is noted with each inhibitor tested between inhibition concentration and sperm motility; the effect is much more pronounced, especially in terms of rendering spermatozoa completely immotile, with fluoride than with either amytal or antimycin A. A similar positive correlation exists between inhibitor concentration and ${ }^{14} \mathrm{CO}_{2}$ evolution. The considerable inhibitory effect of $70 \mathrm{~m} \mu \mathrm{M}$-antimycin $\mathrm{A}$ on ${ }^{14} \mathrm{CO}_{2}$ production is noteworthy. $\left[{ }^{14} \mathrm{C}\right]$ Lactate formation was depressed, as was expected, only with increasing amounts of fluoride. It should be emphasized that precise quantification of the radiochemical product data shown in Table 4 is not possible, due to the suspected presence in monkey spermatozoa of pyruvic acid dismutation reaction (see below) and to the resultant uncertainty about what portion of the metabolically formed (from $\left[\mathrm{U}-{ }^{14} \mathrm{C}\right]$ fructose) pyruvate undergoes nonexergenic conversion to $\left[{ }^{14} \mathrm{C}\right]$ lactate and ${ }^{14} \mathrm{CO}_{2}$.

Other inhibitors studied, but not reported here, include iodoacetate, cyanide and 2- $\mathcal{N}$-heptyl-4-hydroxyquinoline $\mathcal{N}$-oxide. The latter two compounds mimicked the action of amytal and antimycin A. Iodoacetate $(0.9 \mathrm{~mm}) \mathrm{com}-$ pletely abolished $\left[{ }^{14} \mathrm{C}\right]$ lactate and ${ }^{14} \mathrm{CO}_{2}$ production as well as motility.

The results with metabolic inhibitors are best explained on the assumption that respiration in the presence of fructose is not an essential process for sustenance of monkey sperm motility but, instead, serves to support aerobic 
fructolysis as an energy source. This view was supported by simple experiments in which spermatozoa were washed with, and suspended in, Norman-Johnson's solution containing fructose and subsequently incubated under anaerobic conditions for $90 \mathrm{~min}$. At the conclusion of the experiment a slight but perceptible loss of motility was observed, but motility was enhanced on aeration. Spermatozoa which were washed with, and suspended in, Norman-Johnson's solution without fructose were completely immotile at the end of the 90-min anaerobic period. Motility was restored to almost normal levels by aeration.

\section{Dismutation of pyruvic acid}

The failure of high levels of amytal, cyanide, and quinoline $\mathcal{N}$-oxide to suppress completely the formation of ${ }^{14} \mathrm{CO}_{2}$ from $\left[\mathrm{U}-{ }^{14} \mathrm{C}\right]$ fructose suggested the existence of a mechanism for decarboxylation independent of respiration. Such a reaction, first described in spermatozoa by Melrose \& Terner (1953) and Terner (1959), is the dismutation of two molecules of pyruvate to form one molecule each of $\mathrm{CO}_{2}$, acetate and lactate. Efforts to confirm the existence of a

TABLE 5

\begin{tabular}{|c|c|c|c|}
\hline \multirow[t]{2}{*}{ Substrate } & \multirow{2}{*}{$\underset{\text { present }^{*}}{\text { Antimycin } A}$} & \multicolumn{2}{|c|}{$\begin{array}{c}\text { Radiochemical products } \\
\left(\text { counts } / \text { min } \mid \text { fasks } \times 10^{-4}\right)\end{array}$} \\
\hline & & $\mathrm{CO}_{2}$ & Lactate \\
\hline$\left[1-{ }^{14} \mathrm{C}\right]$ Pyruvate & $\bar{t}$ & $\begin{array}{r}13.61 \pm 0.37 \\
9.69 \pm 0.30\end{array}$ & $\begin{array}{l}24 \cdot 19 \pm 0.24 \\
25 \cdot 89 \pm 0.24\end{array}$ \\
\hline$\left[3-{ }^{14} \mathrm{C}\right]$ Pyruvate & $\bar{t}$ & $\begin{array}{l}6.53 \pm 0.25 \\
0.13 \pm 0.04\end{array}$ & $\begin{array}{l}23.43 \pm 0.24 \\
26.56 \pm 0.25\end{array}$ \\
\hline
\end{tabular}

* Antimycin A (final concentration, $2 \cdot 1 \mu \mathrm{M}$ ) was incubated with spermatozoa for 10 min at $37^{\circ} \mathrm{C}$ before addition of substrates. Sperm concentration, $2 \cdot 6 \times 10^{8} / \mathrm{ml}$.

dismutation reaction in monkey spermatozoa by direct measurement of pyruvate and oxygen utilization and lactate and acetate formation met with only partial success. Incubation at $37^{\circ} \mathrm{C}$ for $3.5 \mathrm{hr}$, in a standard Warburg vessel under strictly anaerobic conditions, of $10 \mu$ moles of pyruvate with $1.4 \times 10^{8}$ washed spermatozoa and $10 \mu$ moles of sodium phosphate buffer, $\mathrm{pH} \mathrm{7.2,} \mathrm{in} \mathrm{a}$ volume of $3.2 \mathrm{ml}$, resulted in the disappearance of $5.6 \mu$ moles pyruvate and the formation of $2.0 \mu$ moles lactate. No oxygen was consumed and only a trace of metabolically formed acetate was detected. Accordingly, an indirect approach was taken to demonstrate the dismutation of pyruvate. If such a reaction exists, one would expect the amount of ${ }^{14} \mathrm{CO}_{2}$ evolved from $\left[1-{ }^{14} \mathrm{C}\right]$ pyruvate to be greater than that evolved from an equivalent amount of $\left[3-{ }^{14} \mathrm{C}\right]$ pyruvate. Further, the oxidation of $\left[3-{ }^{14} \mathrm{C}\right]$ pyruvate, as judged from ${ }^{14} \mathrm{CO}_{2}$ production, should be more sensitive than that of the carboxyl-labelled compound to electron transport chain inhibitors. The results of an experiment fulfilling these conditions and strongly suggesting the existence of a dismutation reaction in monkey spermatozoa are shown in Table 5. Spermatozoa were washed with and 
resuspended in N-J-F solution. Incubation was carried out in the presence of 0.5 $\mu \mathrm{C}$ of $\left[1-{ }^{14} \mathrm{C}\right]$ pyruvate $(143 \mathrm{~m} \mu$ moles $)$ or $0.5 \mu \mathrm{C}$ of $\left[3-{ }^{14} \mathrm{C}\right]$ pyruvate $(160 \mathrm{~m} \mu$ moles). Prior counting of stock solutions of the labelled compounds showed that the amount of radio-activity introduced by the addition of carboxyl-labelled pyruvate was $96 \%$ of that of the methyl-labelled compound. As shown in Table 5, over twice as much ${ }^{14} \mathrm{CO}_{2}$ was formed from the former compound as from the latter. Further, the addition of $2 \cdot 1 \mu \mathrm{M}$-antimycin A resulted in 30 and $98 \%$ inhibition, respectively, of ${ }^{14} \mathrm{CO}_{2}$ formation from $\left[1-{ }^{14} \mathrm{C}\right]$ and $\left[3-{ }^{14} \mathrm{C}\right]-$ pyruvate. Inhibition of ${ }^{14} \mathrm{CO}_{2}$ evolution was reflected in increased lactate formation.

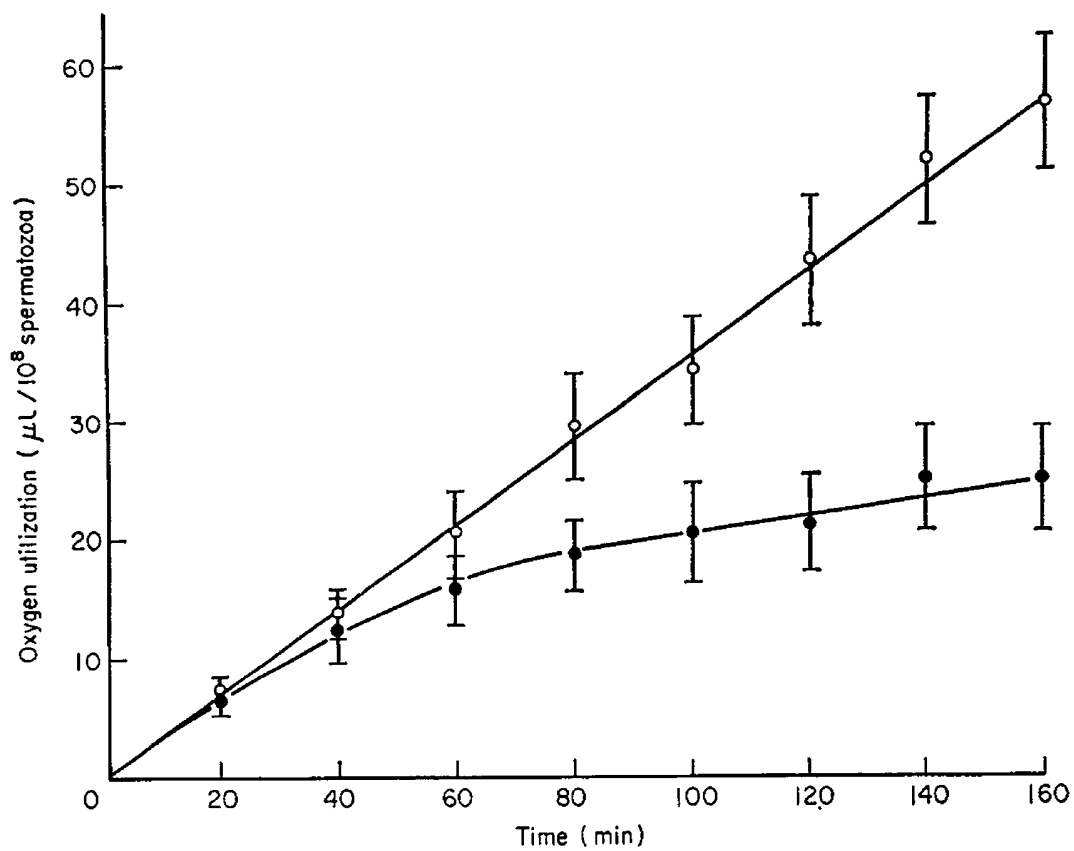

TEXT-FIG. 2. Effect of pyruvate on endogenous respiration of monkey spermatozoa. , Endogenous; $O, 10 \mu$ moles sodium pyruvate, $\mathrm{pH} 7 \cdot 2$. Temperature $37^{\circ} \mathrm{C}$. Each flask contained $0.8 \mathrm{ml}$ sperm suspension in Norman-Johnson's solution (without fructose), $16.2 \mu$ moles sodium phosphate buffer, $\mathrm{pH} 7 \cdot 2$, and substrate when required to a volume of $1.0 \mathrm{ml}$. The centre well contained $0.1 \mathrm{ml} \mathrm{30 \%} \mathrm{KOH}$.

\section{Respiration}

As noted above, measurement of ${ }^{14} \mathrm{CO}_{2}$ formed from $\left[\mathrm{U}-{ }^{14} \mathrm{C}\right]$ fructose of known specific activity by washed spermatozoa permits only an indirect estimation of respiratory capacity. Calculations from the data shown in Table 3 , which were typical of many similar experiments, indicated that the magnitude of the $\mathrm{Zo}_{2}$ value ( $\mu$ l oxygen consumed by $10^{8}$ spermatozoa/hr at $37^{\circ} \mathrm{C}$ ) for monkey spermatozoa, even after subtracting a reasonable value for the contribution due to non-oxidative decarboxylation, would, nevertheless, be no less than 10. Confirmation that washed (Norman-Johnson's solution without fructose) monkey spermatozoa oxidized both endogenous substrates and added pyruvate at rates comparable to that reported for many domestic animals 
(Mann, 1964) is shown in Text-fig. 2. Values represent the mean \pm S.E. of five pooled (two animals each) sperm samples that were obtained from four animals and are expressed in terms of microlitres of oxygen consumed by $10^{8}$ spermatozoa at $37^{\circ} \mathrm{C}$. Almost identical plots have been obtained with succinate, malate and $\alpha$-ketoglutarate. After $160 \mathrm{~min}$ the total oxygen consumed by $10^{8}$ spermatozoa due to endogenous substrates alone was $25 \cdot 6 \pm 4 \cdot 4$ (S.E.) $\mu$ l. This compares with values of $39 \cdot 4 \pm 5 \cdot 7,46 \cdot 6 \pm 7 \cdot 8$ and $52 \cdot 0 \pm 5 \cdot 4 \mu$ l for flasks containing $10 \mu$ moles of $\alpha$-ketoglutarate, malate and succinate, respectively. Correlation of the chemical determination of substrate utilization and oxygen consumption is currently in progress. The $\mathrm{Zo}_{2}$ value for endogenous respiration calculated from Text-fig. 2 is $16 \cdot 0 \pm 3 \cdot 0$. Parallel studies on a single sample of freshly ejaculated human spermatozoa at a level of $3 \cdot 1 \times 10^{7} / \mathrm{ml}$ failed to detect measurable respiration.

TABLE 6

OXIDATION OF $\left[5,6-{ }^{14} \mathrm{C}\right]$ ISOCITRATE AND $\left[{ }^{14} \mathrm{CH}_{3}\right]$ CHOLINE BY WASHED MONKEY SPERMATOZOA

\begin{tabular}{|c|c|c|c|c|c|}
\hline $\begin{array}{l}\text { Exp. } \\
\text { no. }\end{array}$ & $\begin{array}{l}\text { Animal } \\
\text { no. }\end{array}$ & $\begin{array}{c}\text { Sperm } \\
\text { concentration/ } \\
\text { fask } \times 10^{-7}\end{array}$ & Substrate & Inhibitor & $\begin{array}{c}{ }^{14} \mathrm{CO}_{2} \text { evolution } \\
\left(\text { counts } / \text { min } \times 10^{-3}\right)\end{array}$ \\
\hline $\begin{array}{l}1 \\
2 \\
2\end{array}$ & $\begin{array}{l}1504 \\
1504 \\
1504\end{array}$ & $\begin{array}{l}5 \cdot 5 \\
6 \cdot 4 \\
6 \cdot 4\end{array}$ & $\begin{array}{l}{\left[5,6-{ }^{14} \mathrm{C}\right] \text { Isocitrate }} \\
{\left[5,6--^{14} \mathrm{C}\right] \text { Isocitrate }} \\
{\left[5,6-{ }^{14} \mathrm{C}\right] \text { Isocitrate }}\end{array}$ & $\begin{array}{l}\text { None } \\
\text { None } \\
1.87 \mu \text { m-quinoline } \\
\quad \mathcal{N} \text {-oxide }\end{array}$ & $\begin{array}{l}6.87 \pm 0.08 \\
2.47 \pm 0.05 \\
1.52 \pm 0.04\end{array}$ \\
\hline $\begin{array}{l}3 \\
4 \\
4\end{array}$ & $\begin{array}{l}1260 \\
1260 \\
1260\end{array}$ & $\begin{array}{l}6 \cdot 4 \\
6 \cdot 4 \\
6 \cdot 4\end{array}$ & $\begin{array}{l}{\left[{ }^{14} \mathrm{CH}_{3}\right] \text { Choline }} \\
{\left[{ }^{14} \mathrm{CH}_{3}\right] \text { Choline }} \\
{\left[{ }^{14} \mathrm{CH}_{3}\right] \text { Choline }}\end{array}$ & $\begin{array}{l}\text { None } \\
\text { None } \\
2 \cdot 9 \mu \text { M-antimycin A }\end{array}$ & $\begin{array}{l}1.06 \pm 0.03 \\
1.05 \pm 0.03 \\
0.00 \pm 0.00\end{array}$ \\
\hline
\end{tabular}

Inhibitor and spermatozoa incubated for $5 \mathrm{~min}$ at $37^{\circ} \mathrm{C}$ before addition of $0.5 \mu \mathrm{c}\left[{ }^{14} \mathrm{CH}_{3}\right]$ choline or $1 \cdot 0 \mu \mathrm{c}\left[5,6-{ }^{14} \mathrm{C}\right]$ isocitrate.

The capacity of washed monkey spermatozoa to oxidize additional substrates, namely $\left[5,6-{ }^{14} \mathrm{C}\right]$ isocitrate and $\left[{ }^{14} \mathrm{CH}_{3}\right]$ choline to ${ }^{14} \mathrm{CO}_{2}$, is shown in Table 6 . The oxidation of the former is seen to be inhibited partially by 1.87 $\mu$ M-quinoline $\mathcal{N}$-oxide while the latter is completely inhibited by $2.9 \mu \mathrm{M}$ antimycin $A$. As a very rough approximation, by comparison with the data shown in Table 5, isocitrate and choline appear to be oxidized at rates approximately $1 / 10$ and $1 / 50$, respectively, that of pyruvate. Conditions of assay were identical to those cited above under Radiochemical estimation of lactate except for replacement of labelled fructose with the appropriate labelled substrate. Spermatozoa used in Exps. 1 and 2 were washed with $\mathrm{Ca}^{++}$-free Ringer solution rather than Norman-Johnson's solution to prevent dilution of label by citrate present in N-J-F solution.

Following the observation that the rate of monkey sperm endogenous respiration is sufficient to permit manometric measurements, it became possible to re-approach the question of the relation between respiratory rates and motility. As shown in Table 7, spermatozoa washed free of exogenous glycolysable substrates are fully capable of utilizing the oxidation of endogenous substrates exclusively for maintenance of motility. Furthermore, a positive 
correlation exists between the rate of respiration, regulated by titration with quinoline $\mathcal{N}$-oxide, and the concentration of motile spermatozoa. It is noteworthy that $1 \mu$ M-quinoline $\mathcal{N}$-oxide exerts a considerably greater effect on motility in the absence of fructose than it does in its presence (Hoskins \& Patterson, unpublished).

\section{TABLE 7}

THE EFFECT OF 2- $\mathcal{N}$-HEPTYL-4-HYDROXYQUINOLINE $\mathcal{N}$-OXIDE (QNO) ON ENDOGENOUS SPERM RESPIRATION AND MOTILITY*

\begin{tabular}{c|c|c}
\hline QNO concentration & $Z \mathrm{O}_{2}$ & Motility rating \\
\hline $0.0 \mu \mathrm{M}$ & 18 & $9 / 4$ \\
$0 \cdot 1 \mu \mathrm{M}$ & 18 & $9 / 4$ \\
$0.5 \mu \mathrm{M}$ & 12 & $8 / 3$ \\
$1.0 \mu \mathrm{M}$ & 4 & $4 / 1$ \\
\hline
\end{tabular}

* Sperm concentration: $1.5 \times 10^{8} /$ flask. Initial motility rating: $9 / 4$. Other conditions are described in the legend of Text-fig. 2.

\section{DISCUSSION}

The results presented in this paper show that rhesus monkey spermatozoa are capable of rapid rates of both aerobic fructolysis and endogenous respiration. In addition, significant stimulation of endogenous respiration is shown by pyruvate, malate, $\alpha$-ketoglutarate and succinate. Present indications are that respiratory rates are comparable to those reported for bull and ram spermatozoa (Mann, 1964). These observations are interesting in terms of a longstanding controversy (see, for example, MacLeod \& Freund, 1958; Rothschild, $1960)$ over the respiratory capacity of human spermatozoa. This capacity seems to be extremely variable. Nevo (1966), for example, measured the respiratory rates of washed spermatozoa from three human subjects polarographically and reported $\mathrm{Zo}_{2}$ values of $0.5,3.8$ and 10.5 . Variable results in the same range have been obtained by Rothschild (1960). On the basis of data for evolved ${ }^{14} \mathrm{CO}_{2}$, Terner (1962) has indicated that the respiratory rates of human spermatozoa could not exceed a $\mathrm{Zo}_{2}$ value of 1 . It is of additional interest (Hoskins \& Patterson, unpublished observations) that monkey seminal plasma, in contrast to human seminal plasma (see, for example, Nevo, 1966), does not support respiration.

The motility of washed spermatozoa has been shown to be positively correlated with the rate of aerobic fructolysis as measured by accumulation of $\left[{ }^{14} \mathrm{C}\right]$ lactate from $\left[\mathrm{U}-{ }^{14} \mathrm{C}\right]$ fructose. A similar correlation is obtained between the rate of respiration, as measured by oxygen utilization, and motility in the absence of a glycolysable substrate. Incubation of washed spermatozoa containing exogenous fructose with high concentrations of a number of site-specific electron transport chain inhibitors followed by incubation under anaerobic conditions, results in a slight but perceptible loss of motility. Taken as a whole, these results indicate that under aerobic conditions rhesus monkey spermatozoa rely primarily on fructolysis augmented by respiration for maintenance of motility. 
The metabolic significance of the antimycin-sensitive oxidation of $\left[{ }^{14} \mathrm{CH}_{3}\right]$ choline is unknown. Rhesus monkey seminal plasma does, however, contain a potent acid phosphatase which elevates choline levels to 3 to $4 \mathrm{mg} / \mathrm{ml}$ within 2 $\mathrm{hr}$ at room temperature (Hoskins \& Patterson, unpublished observation). The rate of choline oxidation, approximately $1 / 50$ that of pyruvate, indicates that the degradation is of no importance energetically. What is significant is that monkey spermatozoa possess the potential to demethylate choline. It is conceivable, as suggested by Mann (1964), that one physiological function of choline in spermatozoa may be in transmethylation reactions. It is also possible that choline may serve as a source of biosynthetic one-carbon units at the oxidation level of formaldehyde or formate.

\section{ACKNOWLEDGMENTS}

The authors are indebted to Professor T. Mann for advice and encouragement during the course of this investigation and for critical evaluation of the manuscript. We would also like to express our thanks to Dr G. W. Kittinger, Dr G. F. Howard and Dr E. S. West for helpful criticism. The work was supported in part by Grants AM-08958-03 and FR-00163 of the National Institutes of Health.

\section{REFERENCES}

Aalbers, J. G., Mann, T. \& Polge, C. (1961) Metabolism of boar semen in relation to sperm motility and survival. F. Reprod. Fert. 2, 42.

BARKer, J. B. \& Summerson, W. H. (1941) The colorimetric determination of lactic acid in biological material. 7. biol. Chem. 138, 535.

Freund, M., Mixner, J. P. \& MAther, R. E. (1957) Bovine serum metabolism. 2. Influence of sperm concentration and initial fructose level on fructolytic activity. 7. Dairy Sci. 40, 1308.

Freund, M., Mrxner, J. P. \& Mather, R. E. (1959) Bovine semen metabolism. 3. Effect of fructose concentration, fructose per sperm, and seminal plasma factor on fructolysis. F. Dairy Sci. 42, 67.

Friedland, I. M. \& Dietrich, L. S. (1961) A rapid enzymic determination of $L(+)$-lactic acid. Analyt. Biochem. 2, 390.

Hoskins, D. \& Patterson, D. L. (1967) Prevention of coagulum formation with recovery of motile spermatozoa from rhesus monkey semen. F. Reprod. Fert. 13, 337.

MACLEOD, J. \& FREUND, M. (1958) Influence of spermatozoal concentration and initial fructose level on fructolysis in human semen. F. appl. Physiol. 13,501.

ManN, T. (1946) Studies on the metabolism of semen. 3. Fructose as a normal constituent of seminal plasma. Site of formation and function of fructose in semen. Biochem. 7. 40, 481 .

Mann, T. (1948) Fructose content and fructolysis in semen. Practical application in the evaluation of semen quality. F. agric. Sci., Camb. 38, 323.

ManN, T. (1964) Biochemistry of semen and the male reproductive tract. Methuen, London.

Mastroianni, L. \& Manson, W. A. (1963) Collection of monkey semen by electroejaculation. Proc. Soc. exp. Biol. Med. 112, 1025.

Melrose, D. R. \& Terner, C. (1953) The metabolism of pyruvate in bull spermatozoa. Biochem. $\mathcal{F}$. 53, 296.

Nevo, A. C. (1966) Relation between motility and respiration in human spermatozoa. F. Reprod. Fert. $11,19$.

Norman, G., Goldberg, E., Porterfield, I. D. \& Johnson, C. E. (1960) Prolonged survival of human sperm in chemically defined media at room temperature. Nature, Lond. 188, 760.

Passman, J. M., Radin, N. S. \& Cooper, J. A. D. (1956) Liquid scintillation technique for measuring carbon-14-dioxide activity. Analyt. Chem. 28, 484.

Peterson, R. D., Beatty, C. H. \& Bocek, R. M. (1963) Effects of insulin and glucagon on carbohydrate and protein metabolism of adductor muscle and diaphragm. Endocrinology, 72, 71.

Rikmenspoel, R. \& CAPuto, R. (1966) The Michaelis-Menten constant for fructose and for glucose of hexokinase in bull spermatozoa. F. Reprod. Fert. 12, 437. 
RoE, J. H. (1934) A colorimetric method for the determination of fructose in blood and urine. F. biol. Chem. 107, 15.

Rose, I. W. (1955) Acetate kinase of bacteria (acetokinase). In: Methods in Enzymology, Vol. I, p. 591. Eds. S. P. Colowick and N. O. Kaplan. Academic Press, New York.

Rothschild, LoRD (1960) The heat production of human spermatozoa and seminal plasma; with comparative observations on bull semen. Proc. R. Soc. B, 152, 298.

RoTHSGHILD, LORD (1962) Anaerobic heat production and fructolysis of bull spermatozoa at different temperatures. F. exp. Biol. 39, 387.

Terner, C. (1959) The effects of 2,4 dinitrophenol and $p$-nitrophenol on the aerobic and anaerobic metabolism of bull spermatozoa. Biochim. biophys. Acta, 36, 479 .

TERner, G. (1962) Oxidative and biosynthetic reactions in spermatozoa. In: Spermatozoan Motility, p. 89. Ed. D. W. Bishop. American Association for the Advancement of Science, Washington, D.C.

Von Korff, R. W. (1964) Pyruvate-C ${ }^{14}$, purity and stability. Analyt. Biochem. 8, 171. 